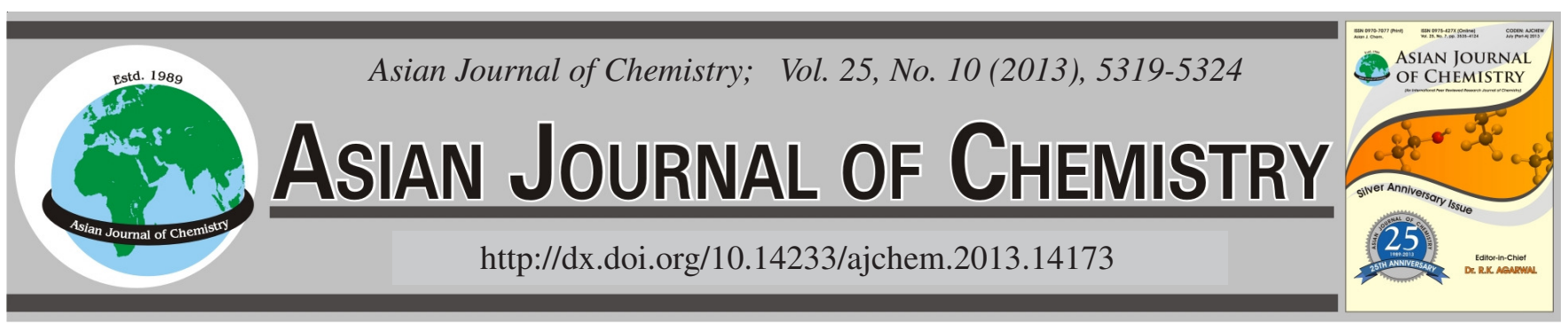

\title{
Adsorption of Humic Acid from Aqueous Solution on Single-Walled Carbon Nanotubes
}

\author{
S.P. Moussavi ${ }^{1}$, M.H. Ehrampoush ${ }^{2}$, A.H. Mahvi ${ }^{3}$, M. Ahmadian ${ }^{4}$ and S. Rahimi, ${ }^{4, *}$
}

${ }^{1}$ Faculty of Public Health, International Branch of Shahid Sadoughi University of Medical Sciences and Health Services, Yazd, Iran ${ }^{2}$ Professor of Environmental Health Engineering, Faculty of Public Health, Shahid Sadoughi University of Medical Sciences, Yazd, Iran ${ }^{3}$ Assistant Professor of Environmental Health Engineering, Faculty of Public Health, Tehran University of Medical Sciences, Tehran, Iran ${ }^{4}$ Social Development \& Health Promotion Research Center, Kermanshah University of Medical Sciences, Kermanshah, Iran

*Corresponding author: Fax: +98 831 4223210; Tel: +98 831 4291980; E-mail: sj.rahimi@yahoo.com

(Received: 7 June 2012;

Accepted: 1 April 2013)

AJC-13196

\begin{abstract}
Humic acid is one of the most important components of humic substances. Its presence in water doesn't directly cause toxicity but can indirectly cause undesirable effects on appearance and taste of water. It can also result in production of undesirable and hazardous products known as disinfectant by-products. In this research, adsorption of humic acid was examined using single-walled carbon nanotubes (SWCNTs). Also, the effect of effective parameters on adsorption process including adsorbent dose, initial concentration of humic acid, contact time and initial solution $\mathrm{pH}$ were evaluated. According to results, as $\mathrm{pH}$ increases, humic acid adsorption increases too. Also, as adsorbent dose and contact time increase, the absorption of humic acid increases too. Results obtained from this study revealed that single-walled carbon nanotubes are able to remove humic acid completely in different concentrations. Therefore, it can be concluded that single-walled carbon nanotubes are considered powerful adsorbents for removing humic acid from aqueous solutions.
\end{abstract}

Key Words: Humic acid, Single-walled carbon nanotubes, Adsorption, Aqueous solution.

\section{INTRODUCTION}

Contamination of surface water and necessity of accessing new water resources is one of the biggest problems of most developing countries. This has allocated most national and international plans to itself. Most water resources throughout the world especially surface and groundwater have huge amounts of natural organic matters (NOMs). Natural organic matters are a product of degradation of aqueous plants and algae available in surface water resources ${ }^{1}$. These matters are a complex and heterogeneous mixture of various organic compounds with different molecular size and properties; they are divided into two main humic and non-humic components. Ratio of humic matters to non-humic matters varies depending on the seasons of the year. The main NOMs are humic substances (HSs) which include humic acid, fulvic acid and humins ${ }^{2-5}$. Humic substances are the most important active components of NOMs which can be found in soils, sediments, surface water and groundwater. Presence of HSs can cause a lot of problems in natural waters ${ }^{6-8}$. Not only does their presence in water affect smell, colour and taste of water but also it affects several processes in purification of drinking water. During chlorination, HSs cause the formation of carcinogenic compounds like trihalomethanes (THMs). They also increase the formation of biofilm in water purification and distribution systems and cause membrane obstruction. These compounds consume chemicals which are used for water purification and will consequently increase purification expenses. Therefore, removing HSs is considered one of the most essential environmental issues ${ }^{9-12}$. Humic acids (HAs) are the main HSs compounds which exist in surface waters. Humic acids are usually soluble in alkaline solutions, while they are insoluble in acidic solutions $(\mathrm{pH}<2)^{2,3}$. Presence of HAs in water doesn't directly cause toxicity but can (after disinfection process) result in the production of undesirable and dangerous products called disinfectant by-products (DBPs). Humic acid is the main precursor of formation of DBPs in natural waters ${ }^{11-13}$. Conventional treatment processes of drinking water remove only 20-50 \% of HSs from water. Therefore, it is very critical to make use of a suitable process to remove the remaining humic acid from drinking water with high amounts of HAs prior to disinfection process ${ }^{5,10}$. Since removal of HSs from water is essential, several methods (e.g. chemical coagulation, membrane separation, adsorption and advanced oxidation) have been developed to remove them ${ }^{4,14}$. Among them, adsorption method has been taken into higher consideration and making use of effective adsorbents in removing humic acid from drinking water has been regarded as a suitable method ${ }^{12}$. Various adsorption methods (e.g., making use of active carbon, zeolite and clay) have been examined in 
this regard ${ }^{7,15,16}$. Carbon nanotubes (CNTs) are a new type of carbon nanomaterials which were discovered in 1991 by Iijiama. Carbon nanotubes are divided into two categories including single-walled carbon nanotubes (SWCNTs) and multi-walled carbon nanotubes (MWCNTs) ${ }^{17-19}$. Carbon nanotubes, as new adsorbents, have been taken into huge account. They are considered powerful adsorbents for removing organic and inorganic contaminants from water because of their unique properties like their small size, large specific surface and area, hallow and tube-like structure, high mechanical strength and electric conduction. Carbon nanotubes are also considered new adsorbents for precondensation and purification of radio-nucleotide matters in huge volumes of wastewater. Many researchers have reported that application of these nano-matters is most suitable and positive in removing and purifying contaminants like micro-pollutants, heavy metals, radio-nucleotides, chemical organic compounds and dangerous materials from gas flows ${ }^{20-23}$. Carbon nanotubes are formed from carbon pure macromolecules; carbon atom film is bond in hexagonal arrays and form cylindrical shapes. Fig. 1 shows internal structure of a SWCNT ${ }^{23-25}$.

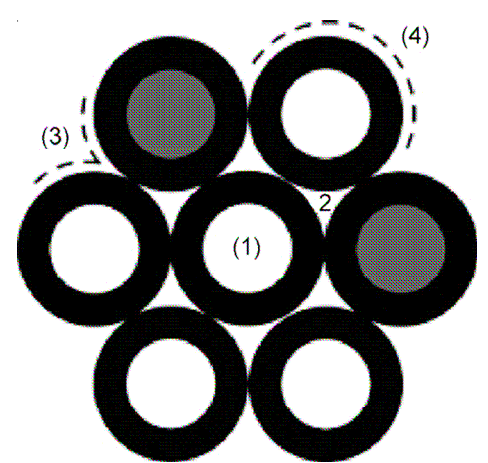

Fig. 1. Different adsorption sites on a homogeneous bundle of partially open-ended SWCNTs: (1) internal, (2) interstitial channel, (3) external groove site and (4) external surface ${ }^{25}$

The aim of the present research is to study the effect of parameters such as adsorbent dose, initial concentration of humic acid, contact time and initial $\mathrm{pH}$ of solution on humic acid adsorption efficiency by single-walled carbon nanotubes (SWCNTs).

\section{EXPERIMENTAL}

Sample preparation: Humic acid was purchased from Aldrich Chemical Company and SWCNT was purchased from Industrial Research Center of Iran Oil Company in Tehran. Single-walled nanotubes with outer diameter of 1-2 nanometers, inner diameter of 0.8-1.1 nanometers, surface area of $700 \mathrm{~m}^{2} / \mathrm{g}$, length of $10 \mu \mathrm{m}$ and purity of $95 \%$ were used in this research as an adsorbent. Stock solution used here was prepared synthetically from dissolution of humic acid powder in distilled water with concentration of $100 \mathrm{mg} / \mathrm{L}$. All solutions were prepared in $0.1 \mathrm{M} \mathrm{NaCl}$, which was the background electrolyte used in the experiments.

Characterization of SWCNTs: This research was undertaken in laboratory scale and SWCNTs were used to remove humic acid from aqueous solutions. In Figs. 2 and 3, pictures related to scanning electron microscopy (SEM)

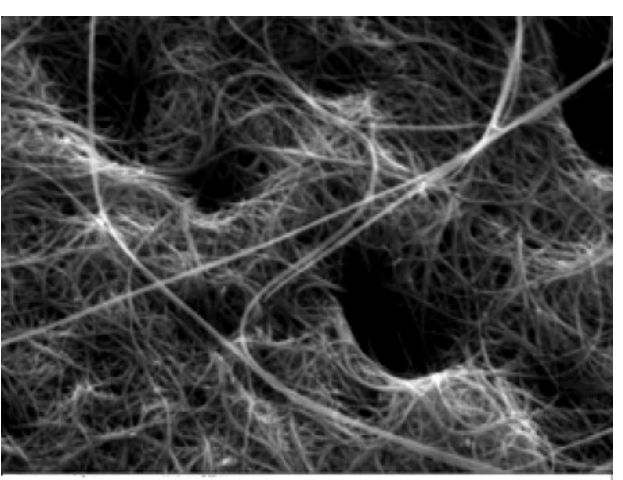

Fig. 2. SEM photograph of SWCNTs

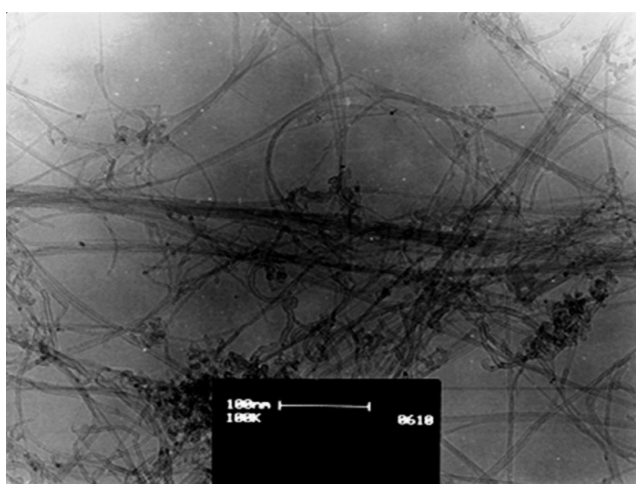

Fig. 3. TEM images of SWCNTs

(Hitachi-Japan, Model S-3700N) and transmission electron microscopy (TEM) (Hitachi-Japan, model H-7100) of SWCNT are shown, respectively.

BET of the single-walled carbon nanotubes which used in this study is presented in Table- 1 .

TABLE-1

BET OF THE SINGLE-WALLED CARBON NANOTUBES

\begin{tabular}{cccccc} 
Sorbent & $\begin{array}{c}\text { Surface } \\
\text { area } \\
\left(\mathrm{m}^{2} / \mathrm{g}\right)\end{array}$ & $\begin{array}{c}\text { Purity } \\
(\%)\end{array}$ & $\begin{array}{c}\text { Outer } \\
\text { diameter } \\
(\mathrm{nm})\end{array}$ & $\begin{array}{c}\text { Inner } \\
\text { diameter } \\
(\mathrm{nm})\end{array}$ & $\begin{array}{c}\text { Average } \\
\text { length } \\
(\mu \mathrm{m})\end{array}$ \\
\hline SWCNT & 700 & 95 & $1-2$ & $0.8-1.1$ & 10 \\
\hline
\end{tabular}

Batch adsorption experiments: Experiments were done in a batch system using certain concentrations of humic acid and certain concentrations of SWCNTs. All compounds being suspended in $0.1 \mathrm{M} \mathrm{NaCl}$ medium as background electrolyte. Experiments were carried out at $23.3^{\circ} \mathrm{C}$ in a closed $250 \mathrm{~mL}$ glass pyramid bottle which contained $100 \mathrm{~mL}$ of humic acid solution. Glass pyramid bottle were placed in an incubator orbital shaker (incubator shaker GFL137) at $140 \mathrm{rpm}$. The pH of each suspension was adjusted to the appropriate value using $0.1 \mathrm{~N} \mathrm{HCl}$ or $\mathrm{NaOH}$ and $\mathrm{pH}$ was measured by $\mathrm{pH}$ meter. In each case, a blank that used to evaluate the adsorption background was prepared using the same experimental conditions. At the end of the equilibrium period, then the suspensions were filtered using by $0.2 \mu \mathrm{m}$ acetate cellulose filter paper (Cartrius, Germany) for ultimate analysis of the acid humic concentration. The adsorption of humic acid was detected using a UV-VIS spectrophotometer (SP-3000 Puls-Japan) at $254 \mathrm{~nm}$. Absorbance measurements were carried out in a $1 \mathrm{~cm}$ quartz cell on a SP-3000 Puls-Japan spectrophotometer. 
Calibration curves were obtained as the samples and blanks under the same experimental conditions. Each experiment was performed three times and experimental results were average values. The amount of humic acid adsorbed per unit mass of SWCNTs at equilibrium $\mathrm{q}_{\mathrm{e}}(\mathrm{mg} / \mathrm{g})$, was calculated from the following equation:

$$
\mathrm{q}_{\mathrm{e}}=\frac{\left(\mathrm{C}_{0}-\mathrm{C}_{\mathrm{e}}\right) \mathrm{V}}{\mathrm{W}}
$$

where $\mathrm{V}$ is the volume of humic acid solution in liters, $\mathrm{C}_{0}$ and $\mathrm{C}_{\mathrm{e}}$ are the initial and equilibrium concentrations, respectively, of the humic acid solutions in $\mathrm{mg} / \mathrm{L}$ and $\mathrm{W}$ is the mass of adsorbent used $(\mathrm{g})$.

Effect of $\mathrm{pH}$ and contact time on adsorption process: To examine the effect of $\mathrm{pH}$ on adsorption process, humic acid solutions with initial concentrations of $5 \mathrm{mg} / \mathrm{L}$ were prepared. $\mathrm{pH}$ of solutions were adjusted by $0.1 \mathrm{~N} \mathrm{HCl}$ or 0.1 $\mathrm{N} \mathrm{NaOH}$ in three acidic, neutral sand alkaline conditions $(4,7$ and 10 , respectively). $0.06 \mathrm{~g}$ of adsorbent was added to 100 $\mathrm{mL}$ of every solution and were stirred for $3 \mathrm{~h}$; sampling was done in time interval of $0.5 \mathrm{~h}$ and in 6 different contact times. Finally, suspension was filtered using $0.2 \mu \mathrm{m}$ acetate cellulose paper filter and then the level of the remaining humic acid was evaluated.

Effect of initial humic acid concentration on adsorption process: To examine the effect of different initial humic acid concentration on adsorption process, humic acid solutions with volume of $100 \mathrm{~mL}$ and initial concentrations of 5, 10, 20 and $30 \mathrm{mg} / \mathrm{L}$ were prepared. Then, their $\mathrm{pH}$ was adjusted at 4 by $\mathrm{HCl}$ or $\mathrm{NaOH}$. $0.04 \mathrm{~g}$ of adsorbent was added to every solution and were stirred for $180 \mathrm{~min}$; sampling was done in time interval of $0.5 \mathrm{~h}$. Finally, suspension was filtered using $0.2 \mu \mathrm{m}$ acetate cellulose paper filter and then the level of the remaining humic acid was evaluated.

Effect of adsorbent dosage on adsorption process: To examine the effect of adsorbent dose on absorption process, humic acid solutions with volume of $100 \mathrm{~mL}$ and initial concentration of $20 \mathrm{mg} / \mathrm{L}$ were prepared. Then various amounts of adsorbent $(0.02,0.04,0.06,0.08$ and $0.1 \mathrm{~g})$ were added to the mentioned solutions and were stirred for $24 \mathrm{~h}$. Their $\mathrm{pH}$ was maintained at 4 using $\mathrm{HCl}$ or $\mathrm{NaOH}$. Finally, suspension was filtered using $0.2 \mu \mathrm{m}$ acetate cellulose paper filter and then the level of the remaining humic acid was evaluated.

\section{RESULTS AND DISCUSSION}

Effect of $\mathbf{p H}$ and contact time: The effect of $\mathrm{pH}$ on adsorption process of HA was analyzed using SWCNT. Generally, adsorption of HA depends on $\mathrm{pH}$ of solution. Solution $\mathrm{pH}$ is an important parameter in adsorption process because it affects the interaction between functional groups of adsorbent and adsorbate. Solution $\mathrm{pH}$ is also an important control parameter which affects adsorption level of humic acid molecules on adsorbent surface. To study the effect of $\mathrm{pH}$ on adsorption of HA, batch experiments were carried out in different $\mathrm{pHs}$ (Fig. 4). As shown here, as $\mathrm{pH}$ decreases from 10-4, adsorption level of humic acid increases and the highest adsorption level is observed in $\mathrm{pH}$ of 4 . Another significant property of humic acid is its size and molecular strucutre which

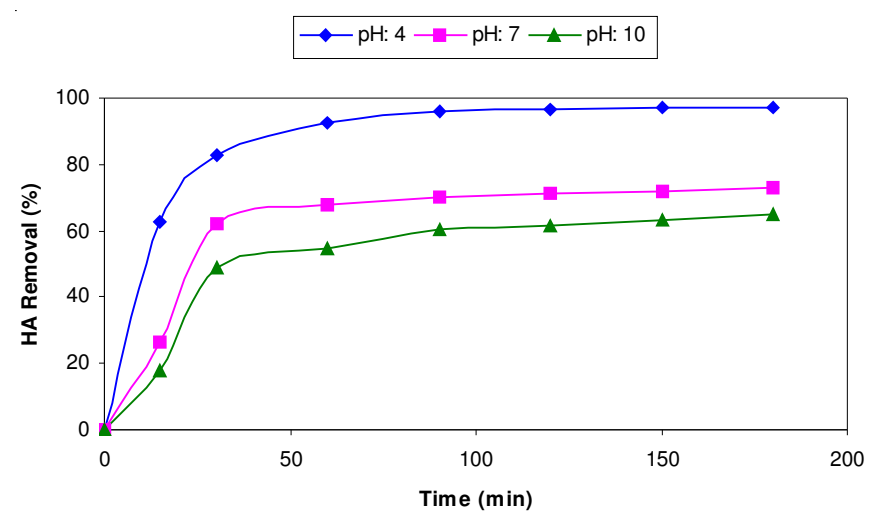

Fig. 4. Effect to $\mathrm{pH}$ solution and contact time on HA removal by SWNT (HA: $20 \mathrm{mg} / \mathrm{L}$, SWNT dose: $0.6 \mathrm{~g} / 100 \mathrm{~mL}$ )

changes to a spherical shape in low pHs and to a linear or extended structure in high $\mathrm{pHs}$; it may decrease adsorption of humic acids in higher $\mathrm{pHs}^{21,23,26,27}$. Thus, size of humic acid macromolecules can be another factor which is related to decreased adsorption capacity in low $\mathrm{pH}$. The effect of contact time on adsorption process has been shown in Fig. 4. According to this figure, as contact time increases from 0-180 min, adsorption capacity of humic acid increases too. According to results obtained from contact time curve, the highest adsorption level occurs in the first $1 \mathrm{~h}$. As time of contact increases more than $1 \mathrm{~h}$, adsorption level doesn't change significantly and stabilizes; thus, the optimum level can be achieved at $1 \mathrm{~h}$. These results show that adsorption process of humic acid is very fast using SWCNTs and this phenomenon is related to a large number of vacant surface sites available on adsorbent surface in initial stages of adsorption process. As time passes, the remaining vacant surface sites are toughly occupied by adsorbate due to repulsive forces among molecules of solute on solid and bulk phases ${ }^{21-25}$.

Effect of HA initial concentration: The adsorption capacity of HA is a function of humic acid initial concentration. To study the effect of HA initial concentration on adsorption process, solutions with initial concentrations of 5, 10, 20 and $30 \mathrm{mg} / \mathrm{L}$ were used (Fig. 5). The initial HA concentrations provide an important driving force to overcome the mass transfer resistance of the HA between the aqueous phases and the solid phases, so increasing initial concentrations would enhance the adsorption capacity of humic acid. It is logical in this matter that active adsorption sites available on adsorbent are lower in initial concentrations due to very high ratios ${ }^{22,24,25}$. The equilibration time for the adsorption of HA at different concentrations ranged between 15 and $180 \mathrm{~min}$. With decreasing initial humic acid concentrations, adsorption rate increased.

Effect of adsorbent dose: Adsorbent dose is one of the most important parameters in adsorption process which is as a result of effective role of adsorbent capacity for adsorbing pollutants on its surface. In this research, the effect of adsorbent dose on HA adsorption process was analyzed using SWCNT (Fig. 6). As shown in this figure, as adsorbent level increases, HA adsorption process increases too. It is as a result of increased number of adsorption sites for a certain level of adsorbate or HA. Initially, rapid increase in adsorption with the increase in adsorbent dose can be attributed to greater surface area and availability of more adsorption sites ${ }^{5,10,13}$. 


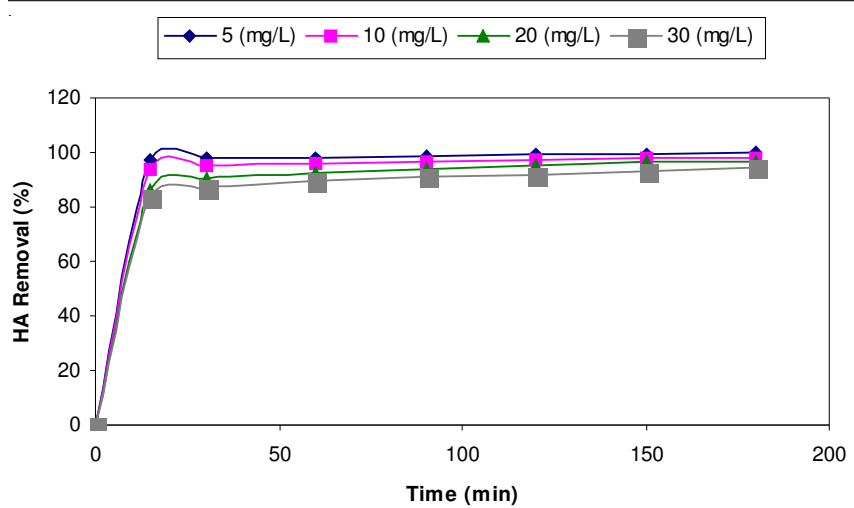

Fig. 5. Effect of initial HA concentrations on HA adsorption (SWNT dose: $0.4 \mathrm{~g} / \mathrm{L}, \mathrm{pH}: 4)$

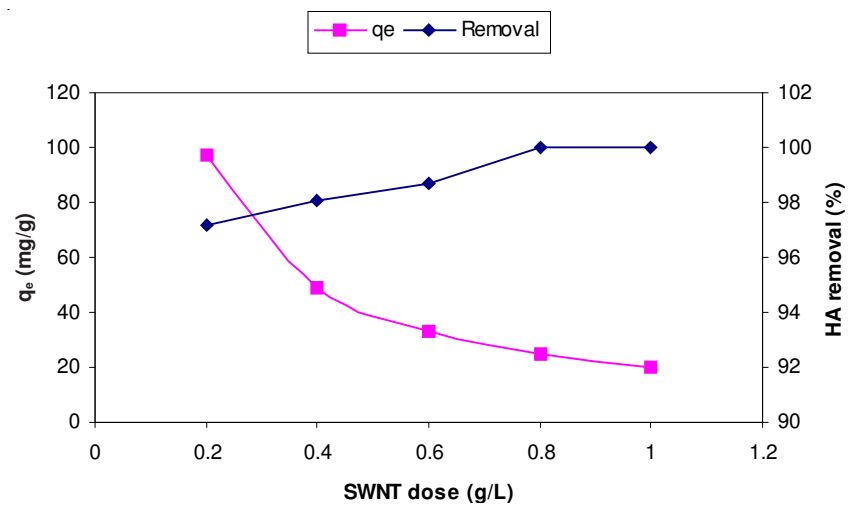

Fig. 6. Effect of SWNT dose on adsorption of HA (HA: $20 \mathrm{mg} / \mathrm{L}$, pH: 4 and $24 \mathrm{~h}$ contact time)

Adsorption isotherm experiments: Application of adsorption isotherms, which are used for description of interaction between adsorbent and adsorbate in various systems, is very useful. The isotherm equations used in this study are presented in Table- 2 .

TABLE-2

ISOTHERM EQUATIONS FOR HA ADSORPTION ON SWNT

\begin{tabular}{|c|c|c|}
\hline Isotherm & Equation & Ref. \\
\hline Linear & $\mathrm{q}_{\mathrm{e}}=\mathrm{K}_{\mathrm{p}} \mathrm{C}_{\mathrm{i}}$ & 28 \\
\hline $\begin{array}{l}\text { Brunauer-Emmett- } \\
\text { Teller (BET) }\end{array}$ & $\mathrm{q}_{\mathrm{e}}=\frac{\mathrm{Q}_{0} \mathrm{bC}}{\left(\mathrm{S}_{\mathrm{w}}-\mathrm{C}_{\mathrm{i}}\right)\left[1+(\mathrm{b}-1)\left(\mathrm{C}_{\mathrm{i}} / \mathrm{S}_{\mathrm{w}}\right)\right]}$ & 29 \\
\hline Freundlich & $\mathrm{q}_{\mathrm{e}}=\mathrm{K}_{\mathrm{f}} \mathrm{C}_{\mathrm{i}}^{\left(1 / \mathrm{n}_{\mathrm{f}}\right)}$ & 30 \\
\hline $\begin{array}{l}\text { Freundlich with linear } \\
\text { partitioning (F-P) }\end{array}$ & $\mathrm{q}_{\mathrm{e}}=\mathrm{K}_{\mathrm{f}} \mathrm{C}_{\mathrm{i}}^{\left(1 / \mathrm{n}_{\mathrm{f}}\right)}+\mathrm{K}_{\mathrm{p}} \mathrm{C}_{\mathrm{i}}$ & 31 \\
\hline $\begin{array}{c}\text { Generalized } \\
\text { Langmuir-Freundlich } \\
\text { (GLF) }\end{array}$ & $\mathrm{q}_{\mathrm{e}}=\frac{\mathrm{Q}_{0}\left(\mathrm{bC}_{\mathrm{i}}\right)^{\left(1 / \mathrm{n}_{\mathrm{g}}\right)}}{1+\left(\mathrm{bC}_{\mathrm{i}}\right)^{\left(1 / \mathrm{n}_{\mathrm{g}}\right)}}$ & 32 \\
\hline Langmuir & $\mathrm{q}_{\mathrm{e}}=\frac{\mathrm{Q}_{0} \mathrm{bC}_{\mathrm{i}}}{1+\mathrm{bC}_{\mathrm{i}}}$ & 33 \\
\hline $\begin{array}{l}\text { Langmuir with linear } \\
\text { partitioning (L-P) }\end{array}$ & $\mathrm{q}_{\mathrm{e}}=\frac{\mathrm{Q}_{0} \mathrm{bC}_{\mathrm{i}}}{1+\mathrm{bC}_{\mathrm{i}}}+\mathrm{K}_{\mathrm{p}} \mathrm{C}_{\mathrm{i}}$ & 34 \\
\hline Polanyi & $\mathrm{q}_{\mathrm{e}}=\mathrm{Q}_{0} 10^{-\mathrm{A}\left[\log \left(\mathrm{S}_{\mathrm{w}} / \mathrm{C}_{\mathrm{i}}\right)\right]^{\mathrm{B}}}$ & 35 \\
\hline $\begin{array}{l}\text { Polanyi with linear } \\
\text { partitioning }(\mathrm{P}-\mathrm{P})\end{array}$ & $\mathrm{q}_{\mathrm{e}}=\mathrm{Q}_{0} 10^{-\mathrm{A}\left[\log \left(\mathrm{S}_{\mathrm{w}} / \mathrm{C}_{\mathrm{i}}\right)\right]^{\mathrm{B}}}+\mathrm{K}_{\mathrm{p}} \mathrm{C}_{\mathrm{i}}$ & 35 \\
\hline Toth & $\mathrm{q}_{\mathrm{e}}=\frac{\mathrm{Q}_{0} \mathrm{bC}_{\mathrm{i}}}{\left[1+\left(\mathrm{bC}_{\mathrm{i}}\right)^{\mathrm{n}_{\mathrm{t}}}\right]^{\left(1 / \mathrm{n}_{\mathrm{t}}\right)}}$ & 36 \\
\hline
\end{tabular}

Isotherm adsorption curves of humic acid (using SWCNTs) are shown in Fig. 7. According to these figures, experiment results can be described and defined by Langmuir and Freundlich isotherm model. The Freundlich isotherm describes reversible adsorption and is not restricted to the formation of the monolayer. The Freundlich equation predicts that the HA concentration on the adsorbent will increase so long as there is an increased in the HA concentration in the liquid. Summary of the parameter estimates for HA adsorption on SWCNTs are shown in Tables 3 and 4. The result shows that Freundlich isotherm best-fit the equilibrium data for adsorption of HA on SWCNTs.
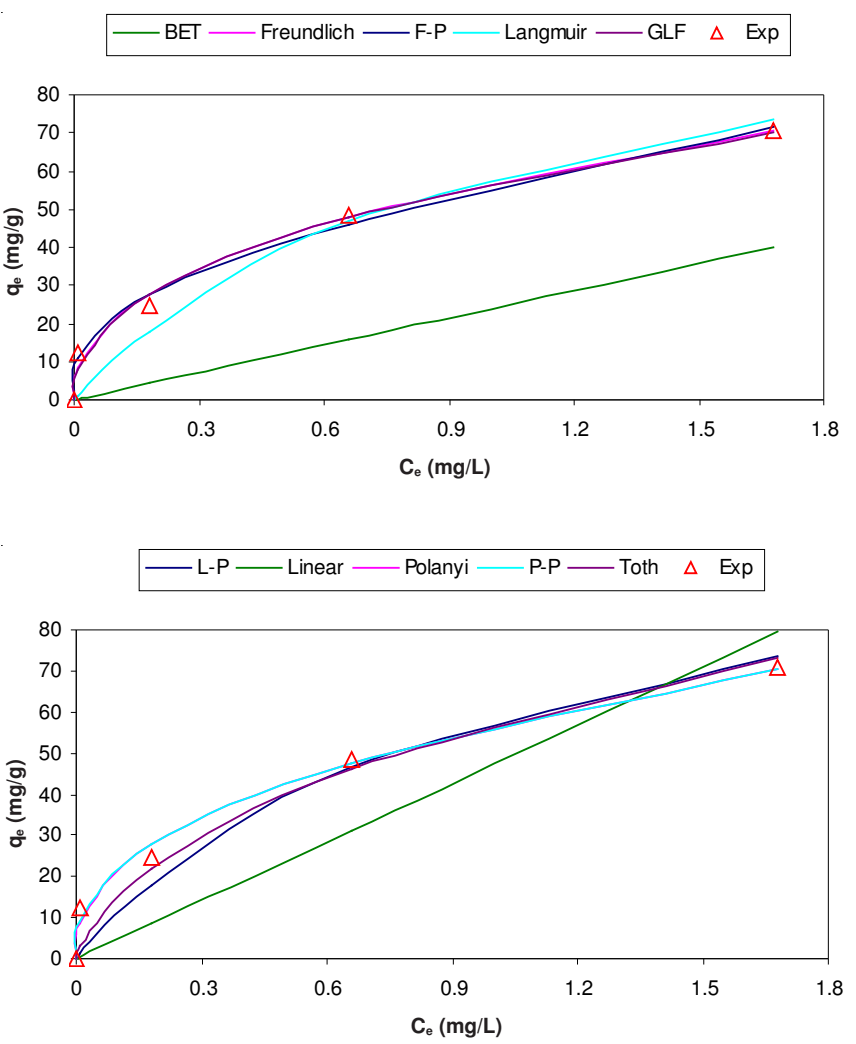

Fig. 7. Isotherms for the adsorption of HA onto the SWCNTs

Adsorption kinetic experiments: The equation and linear form of kinetics used in this study are presented in Table5. Adsorption of HA on SWCNTs showed similar kinetic behaviours for the different HA concentration. Kinetic adsorption curves of humic acid (using SWCNTs) are shown in Fig. 8. At first, humic acid is adsorbed rapidly and after $1 \mathrm{~h}$ the highest adsorption level for various concentrations of 5 , 10,20 and $30 \mathrm{mg} / \mathrm{L}$ was $95 \%$. Equilibrium time in adsorption experiments was fixed to determine kinetic ( $3 \mathrm{~h}$ to guaranty equilibrium adsorption). Pseudo-second-order kinetic model was more suitable for removing HA on SWCNTS and was better than pseudo-first-order model. Thus, kinetic constants were calculated according to pseudo-second-order kinetic model. It is reasonable to conclude that the reactivity of the SWCNTs have significantly higher density of active sites due to its tremendous SWCNTs and thus exhibit stronger affinity to the HA. The parameters obtained from various kinetics models are presented in Table- 6 . 


\begin{tabular}{|c|c|c|c|c|c|c|c|c|c|}
\hline \multicolumn{10}{|c|}{$\begin{array}{c}\text { TABLE-3 } \\
\text { SUMMARY OF PARAMETER ESTIMATES FOR HL }\end{array}$} \\
\hline Isotherm & Parameter & Estimate & $\mathrm{Cl}_{\text {Low }}$ & $\mathrm{Cl}_{\text {High }}$ & Isotherm & Parameter & Estimate & $\mathrm{Cl}_{\text {Low }}$ & $\mathrm{Cl}_{\text {High }}$ \\
\hline \multirow{3}{*}{ BET } & $\mathrm{b} \times \mathrm{Q}_{0}$ & $1.00 \times 10^{6}$ & $-1.16 \times 10^{6}$ & $3.16 \times 10^{6}$ & \multirow{4}{*}{ L-P } & $\mathrm{b} \times \mathrm{Q}_{0}$ & $1.17 \times 10^{2}$ & $-1.16 \times 10^{2}$ & $3.51 \times 10^{2}$ \\
\hline & $\mathrm{b}$ & 0.76 & $\mathrm{n} / \mathrm{a}$ & $\mathrm{n} / \mathrm{a}$ & & $\mathrm{b}$ & 1.01 & -2.55 & 4.55 \\
\hline & $\mathrm{Q}_{0}$ & $1.32 \times 10^{6}$ & $\mathrm{n} / \mathrm{a}$ & $\mathrm{n} / \mathrm{a}$ & & $\mathrm{Q}_{0}$ & $1.16 \times 10^{2}$ & $\mathrm{n} / \mathrm{a}$ & $\mathrm{n} / \mathrm{a}$ \\
\hline \multirow{2}{*}{ Freundlich } & $\mathrm{K}_{\mathrm{f}}$ & 56.75 & 46.57 & 66.93 & & $\mathrm{~K}_{\mathrm{p}}$ & $1.01 \times 10^{-6}$ & $\mathrm{n} / \mathrm{a}$ & $\mathrm{n} / \mathrm{a}$ \\
\hline & $1 / n_{f}$ & 0.42 & 0.19 & 0.63 & \multirow{3}{*}{ Polanyi } & $\mathrm{Q}_{0}$ & $1.67 \times 10^{4}$ & $-3.73 \times 10^{6}$ & $3.76 \times 10^{6}$ \\
\hline \multirow{3}{*}{ F-P } & $\mathrm{K}_{\mathrm{f}}$ & 41.35 & $-1.56 \times 10^{2}$ & $2.39 \times 10^{2}$ & & A & 0.74 & -62.35 & 63.83 \\
\hline & $1 / n_{\mathrm{f}}$ & 0.29 & -1.56 & 2.14 & & B & 0.79 & -28.85 & 30.43 \\
\hline & $\mathrm{K}_{\mathrm{p}}$ & 13.92 & $-1.59 \times 10^{2}$ & $1.88 \times 10^{2}$ & \multirow{4}{*}{ P-P } & $\mathrm{Q}_{0}$ & $2.98 \times 10^{4}$ & $-7.98 \times 10^{6}$ & $8.04 \times 10^{6}$ \\
\hline \multirow{3}{*}{ GLF } & $\mathrm{Q}_{0}$ & $9.32 \times 10^{2}$ & $-1.59 \times 10^{-5}$ & $1.61 \times 10^{5}$ & & A & 0.91 & -78.84 & 80.65 \\
\hline & $\mathrm{b}$ & $1.91 \times 10^{-3}$ & -0.89 & 0.91 & & B & 0.72 & -28.53 & 29.96 \\
\hline & $\left(1 / n_{g}\right)$ & 0.44 & -3.34 & 4.22 & & $\mathrm{~K}_{\mathrm{p}}$ & 24.06 & $\mathrm{n} / \mathrm{a}$ & $\mathrm{n} / \mathrm{a}$ \\
\hline \multirow{3}{*}{ Langmuir } & $\mathrm{b} \times \mathrm{Q}_{0}$ & $1.17 \times 10^{2}$ & $-1.16 \times 10^{2}$ & $3.51 \times 10^{2}$ & \multirow{4}{*}{ Toth } & $\mathrm{b} \times \mathrm{Q}_{0}$ & $8.45 \times 10^{2}$ & $-1.46 \times 10^{5}$ & $1.47 \times 10^{5}$ \\
\hline & $\mathrm{b}$ & 1.01 & -2.55 & 4.55 & & B & 0.99 & -0.47 & 0.49 \\
\hline & $\mathrm{Q}_{0}$ & $1.16 \times 10^{2}$ & $\mathrm{n} / \mathrm{a}$ & $\mathrm{n} / \mathrm{a}$ & & $\mathrm{Q}_{0}$ & $8.54 \times 10^{2}$ & $\mathrm{n} / \mathrm{a}$ & $\mathrm{n} / \mathrm{a}$ \\
\hline Linear & $\mathrm{K}_{\mathrm{p}}$ & 47.23 & 19.13 & 75.33 & & $\mathrm{n}_{\mathrm{T}}$ & 0.26 & -17.81 & 18.32 \\
\hline
\end{tabular}

\begin{tabular}{|c|c|c|c|c|c|}
\hline \multicolumn{6}{|c|}{$\begin{array}{c}\text { TABLE-4 } \\
\text { SUMMARY OF SELECTED DIAGNOSTICS FOR } \\
\text { HUMIC ACID ADSORPTION ON SWCNTS }\end{array}$} \\
\hline \multirow[b]{2}{*}{ Isotherm } & \multicolumn{5}{|c|}{ Parameter } \\
\hline & AICc & $\mathrm{R}_{\mathrm{y}}^{2}$ & $\mathrm{R}_{\mathrm{N}}^{2}$ & $\mathrm{M}^{2}$ & $\begin{array}{c}\text { Linearity } \\
\text { Assessment }\end{array}$ \\
\hline$\overline{\mathrm{BET}}$ & 29.87 & 0.94 & 0.92 & $6.36 \times 10^{-2}$ & Uncertain \\
\hline Freundlich & 23.79 & 0.9 & 0. & $5.26 \times 10^{-3}$ & \\
\hline F-P & 1.02 & 0.99 & 0.96 & 0.15 & Non- \\
\hline GLF & 1.01 & 0.99 & 0.94 & $6.52 \times 10^{-3}$ & Non-Linear \\
\hline Langmuir & 31.28 & 0.99 & 0.99 & 0.55 & Non-Linear \\
\hline Linear & 25.04 & 0.94 & 0.77 & $1.32 \times 10^{-9}$ & Linear \\
\hline L-P & 31.29 & 0.99 & 0.99 & 0.53 & Non-Linear \\
\hline Polanyi & 1.03 & 0.99 & 0.95 & $5.73 \times 10^{3}$ & Non-Linear \\
\hline P-P & 1.02 & 0.99 & 0.96 & $5.95 \times 10^{3}$ & Non-Linear \\
\hline Toth & 1.01 & 0.99 & 0.92 & $5.18 \times 10^{-3}$ & Non-Linear \\
\hline
\end{tabular}

\begin{tabular}{lllll}
\hline & $\mathrm{pH}: 4$ & $\mathrm{pH}: 7$ & $\mathrm{pH}: 10 \longrightarrow \mathrm{pH}: 4 \cdots \cdots$ & $\mathrm{pH}: 7----\mathrm{pH}: 10$ \\
\hline
\end{tabular}

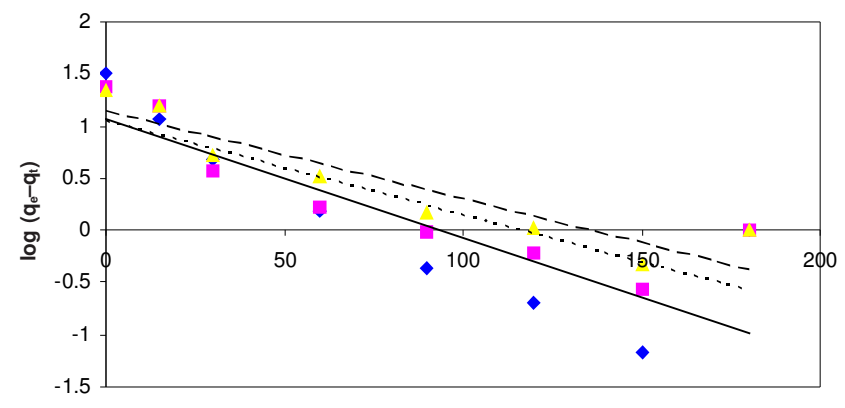

$\mathbf{t}$
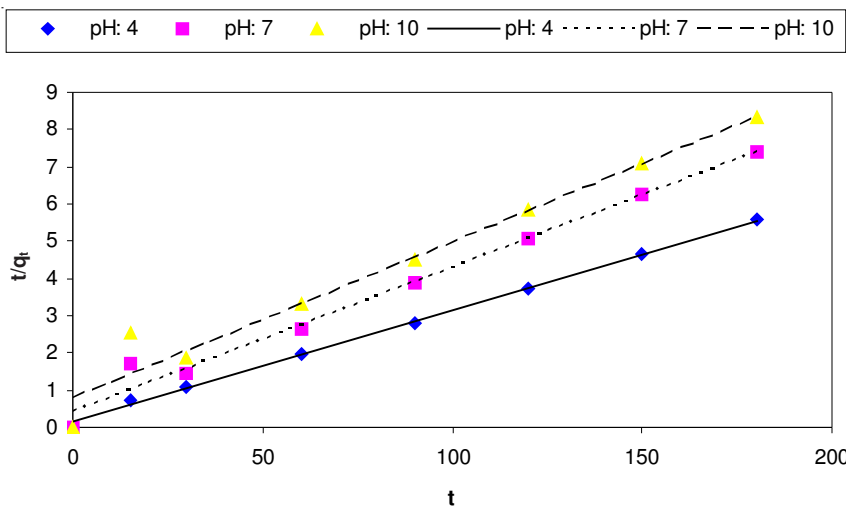
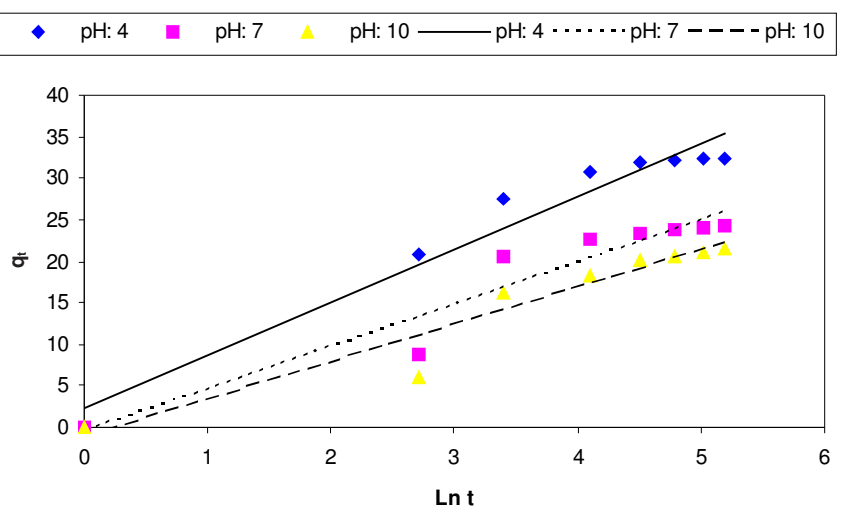

$\begin{array}{lllll}\mathrm{pH}: 4 & \mathrm{pH}: 7 & \mathrm{pH}: 10 \longrightarrow \mathrm{pH}: 4 \cdots \cdots & \cdots & \cdots\end{array}$

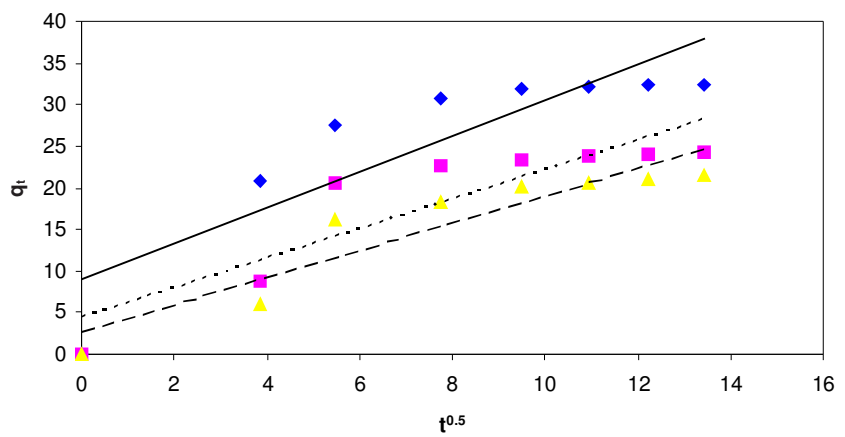

Fig. 8. Adsorption kinetics of humic acid on SWCNTs and pseudo-secondorder model

\section{Conclusion}

Results of this study reveled that as $\mathrm{pH}$ decreases from 10-4, adsorption levels of humic acid increase and the highest adsorption level is obtained in $\mathrm{pH}$ of 4 . When levels of adsorbent dose is fixed in $0.06 \mathrm{~g}$ per $100 \mathrm{~mL}$ of solution, as contact time increases from 15-180 min, adsorption level of humic acid increases; the highest adsorption level occurs in the first $1 \mathrm{~h}$. As level of adsorbent dose increases, adsorption level of humic acid also increases. Single-walled carbon nanotubes can completely remove different concentrations of humic acid in $\mathrm{pH}$ of 4 and in contact time of $3 \mathrm{~h}$. Results also showed that Single-walled carbon nanotubes are considered a powerful adsorbent in removing humic acids and can be effectively used to remove these organic matters. 


\begin{tabular}{|c|c|c|c|c|}
\hline & & & \multicolumn{2}{|c|}{ EQUATION AND LINE } \\
\hline \multicolumn{2}{|c|}{ Kinetic } & & \multicolumn{2}{|c|}{ Equation } \\
\hline \multicolumn{2}{|c|}{ Pseudo first order } & & \multicolumn{2}{|c|}{$\frac{\mathrm{dq}_{\mathrm{t}}}{\mathrm{dt}}=\mathrm{k}_{1}\left(\mathrm{q}_{\mathrm{e}}-\mathrm{q}_{\mathrm{t}}\right)$} \\
\hline \multicolumn{2}{|c|}{ Pseudo second order } & & \multicolumn{2}{|c|}{$\frac{\mathrm{dq}_{\mathrm{t}}}{\mathrm{dt}}=\mathrm{k}_{2}\left(\mathrm{q}_{\mathrm{e}}-\mathrm{q}_{\mathrm{t}}\right)^{2}$} \\
\hline \multicolumn{2}{|c|}{ Elovich } & & \multicolumn{2}{|c|}{$\frac{\mathrm{dq}_{\mathrm{t}}}{\mathrm{dt}}=\alpha \exp \left(-\beta \mathrm{q}_{\mathrm{t}}\right)$} \\
\hline \multicolumn{3}{|c|}{ Intraparticle diffusion } & \multicolumn{2}{|c|}{-} \\
\hline \multicolumn{5}{|c|}{$\begin{array}{c}\text { TABLE-6 } \\
\text { THE PARAMETERS OBTAINED FROM VARIOUS KINETICS } \\
\text { MODELS USING DIFFERENT HA CONCENTRATIONS }\end{array}$} \\
\hline Kinetic & Parameter & pH: 4 & pH: 7 & pH: 10 \\
\hline \multirow{3}{*}{$\begin{array}{l}\text { Pseudo first } \\
\text { order }\end{array}$} & $\mathrm{k}_{1}$ & 0.026 & 0.021 & 0.019 \\
\hline & $\mathrm{q}_{\mathrm{e}} \mathrm{cal}$ & 11.68 & 11.16 & 13.63 \\
\hline & $\mathrm{R}^{2}$ & 0.68 & 0.75 & 0.86 \\
\hline \multirow{4}{*}{$\begin{array}{l}\text { Pseudo } \\
\text { second } \\
\text { order }\end{array}$} & $\mathrm{k}_{2}$ & 0.0064 & 0.0034 & 0.0023 \\
\hline & $\mathrm{q}_{\mathrm{e}} \mathrm{cal}$ & 33.22 & 25.91 & 23.81 \\
\hline & $\mathrm{h}$ & 7.06 & 2.28 & 1.31 \\
\hline & $\mathrm{R}^{2}$ & 0.99 & 0.98 & 0.96 \\
\hline \multirow{3}{*}{ Elovich } & $\alpha$ & 0.82 & 1.04 & 3.26 \\
\hline & $\beta$ & 0.16 & 0.19 & 0.79 \\
\hline & $\mathrm{R}^{2}$ & 0.96 & 0.92 & 0.93 \\
\hline \multirow{3}{*}{$\begin{array}{l}\text { Intraparticle } \\
\text { diffusion }\end{array}$} & $\mathrm{K}_{\mathrm{dif}}$ & 2.15 & 1.78 & 1.64 \\
\hline & $\mathrm{C}$ & 9.04 & 4.35 & 2.51 \\
\hline & $\mathrm{R}^{2}$ & 0.76 & 0.81 & 0.86 \\
\hline
\end{tabular}

TABLE-5

NEAR FORM OF KINETICS

Equation Linear form

Reference

$$
\begin{gathered}
\log \left(\mathrm{q}_{\mathrm{e}}-\mathrm{q}_{\mathrm{t}}\right)=\log \left(\mathrm{q}_{\mathrm{e}}\right)-\frac{\mathrm{k}_{1}}{2.303} \mathrm{t} \\
\frac{\mathrm{t}}{\mathrm{q}_{\mathrm{t}}}=\left(\frac{1}{\mathrm{k}_{2} \mathrm{q}_{\mathrm{e}}^{2}}\right)+\left(\frac{1}{\mathrm{q}_{\mathrm{e}}}\right) \mathrm{t} \\
\mathrm{q}_{\mathrm{e}}=\left(\frac{1}{\beta}\right) \ln (\alpha \beta)+\left(\frac{1}{\beta}\right) \ln \mathrm{t} \\
\mathrm{q}_{\mathrm{t}}=\mathrm{K}_{\text {dif }} \mathrm{t}^{0.5}+\mathrm{C}
\end{gathered}
$$

$\mathrm{T} \quad$ : absolute temperature $(\mathrm{K})$

$\alpha \quad$ : initial adsorption rate $(\mathrm{mg} / \mathrm{g}$ min)

$\beta \quad$ : desorption constant (g/mg)

$\varepsilon \quad$ : Polanyi potential

\section{REFERENCES}

1. H.C. Kim, S.J. Park, C.G. Lee, Y.U. Han, J.A. Park and S.B. Kim, Environ. Eng. Res., 14, 41 (2009).

2. Y. Zhan, J. Lin, Y. Qiu, N. Gao and Z. Zhu, Front. Environ. Sci. Engin. China, 5, 65 (2011).

3. M.N. Moura, M.J. Martín and F.J. Burguillo, J. Hazard. Mater., 149, 42 (2007).

4. Y. Zhan, Z. Zhu, J. Lin, Y. Qiu and J. Zhao, J. Environ. Sci. (China), 22, 1327 (2010).

5. C.E. Gokce, S. Guneysu, S. Aydin and S. Arayici, Open Environ. Pollut. Toxicol. J., 1, 43 (2009).

6. L. Liang, L. Luo and S.Z. Zhang, Colloid. Surf. A, 384, 126 (2011).

7. L. Zhao, F. Luo, J.M. Wasikiewicz, H. Mitomo, N. Nagasawa, T. Yagi, M. Tamada and F. Yoshii, Bioresour. Technol., 99, 1911 (2008).

8. S. Deng and R. Bai, J. Colloid Interf. Sci., 280, 36 (2004).

9. C. Lu and F. Su, Sep. Purif. Technol., 58, 113 (2007).

10. AAM. Daifullah, B.S Girgis and H.M.H Gad, Colloid. Surf. A, 235, 1 (2004).

11. R.P. Liu, Y.L. Yang, G.B. Li, W.J. He and H.D. Han, Front. Environ. Sci. Engin. China, 1, 240 (2007).

$\mathrm{R}_{\mathrm{y}}^{2} \quad$ : Correlation between measured and simulated data

AICc : Corrected Akaike Information Criterion

$\mathrm{R}^{2}{ }_{\mathrm{N}}$ : Normal probability correlation coefficient

$\mathrm{M}^{2}$ : Linssen index

$\mathrm{A}_{\mathrm{T}} \quad$ : Temkin constant $(\mathrm{L} / \mathrm{g})$

$\mathrm{B}_{\mathrm{T}}$ : constant related to heat of adsorption $(\mathrm{mg} / \mathrm{L})$

C : thickness of the boundary layer $(\mathrm{mg} / \mathrm{g})$

$\mathrm{C}_{0}$ : initial concentration $(\mathrm{mg} / \mathrm{L})$

$\mathrm{C}_{\mathrm{e}}$ : equilibrium concentration in solution $(\mathrm{mg} / \mathrm{L})$

$\mathrm{C}_{\mathrm{s}} \quad$ : saturation concentration in solution $(\mathrm{mmol} / \mathrm{L})$

$\mathrm{C}_{\mathrm{t}}$ : equilibrium concentration in solution at time $\mathrm{t}(\mathrm{mg} / \mathrm{L})$

$\mathrm{h}$ : initial sorption rate ( $\mathrm{mg} / \mathrm{g} \mathrm{min})$

$\mathrm{k}_{1} \quad$ : Pseudo first-order rate constant $(\mathrm{L} / \mathrm{min})$

$\mathrm{k}_{2}$ : Pseudo second-order rate constant ( $\mathrm{mg} / \mathrm{g} \mathrm{min}$ )

$\mathrm{K}_{\mathrm{B}}$ : BET constant

$\mathrm{K}_{\text {dif }} \quad$ : Intraparticle diffusion rate constant ( $\mathrm{mg} / \mathrm{g} \mathrm{min}^{0.5}$ )

$\mathrm{K}_{\mathrm{D}-\mathrm{R}}$ : adsorption energy $\left(\mathrm{mol}^{2} / \mathrm{kJ}^{2}\right)$

$\mathrm{K}_{\mathrm{f}} \quad$ : Freundlich isotherm constants $(\mathrm{L} / \mathrm{g})$

$\mathrm{K}_{\mathrm{G}} \quad$ : saturation constant $(\mathrm{mg} / \mathrm{L})$

$\mathrm{K}_{\mathrm{L}}$ : Langmuir isotherm constants (L/mg)

$\mathrm{n} \quad$ : adsorption intensity

$\mathrm{N}_{\mathrm{b}} \quad$ : cooperative binding constant

$\mathrm{q}_{\mathrm{e}} \quad$ : equilibrium adsorbent concentration on adsorbent (mg/g)

$\mathrm{q}_{\mathrm{e}}$ cal : calculated values of $\mathrm{q}_{\mathrm{e}}(\mathrm{mg} / \mathrm{g})$

$\mathrm{Q}_{\mathrm{m}} \quad$ : maximum monolayer capacity (mg/g)

$\mathrm{q}_{\mathrm{t}} \quad$ : adsorbed concentration at time $\mathrm{t}(\mathrm{mg} / \mathrm{g})$

$\mathrm{R} \quad$ : universal gas constant, $8.314 \mathrm{~J} / \mathrm{mol} \mathrm{K}$

$\mathrm{R}^{2}$ : correlation coefficients

$\mathrm{R}_{\mathrm{L}} \quad$ : dimensional separation factor

12. S. Vreysen and A. Maes, Appl. Clay Sci., 38, 237 (2008).

13. Sh. Maghsoodloo, B. Noroozi, A.K. Haghi and G.A. Sorial, J. Hazard. Mater., 191, 380 (2011).

14. T. Hartono, S.B. Wang, Q. Ma and Z.H. Zhu, J. Colloid Interf. Sci., 333, 114 (2009).

15. C.P. Schulthess and C.P. Huang, Soil Sci. Soc. Am. J., 55, 34 (1991).

16. M. Khraisheh, M.A. Al-Ghouti and C.A. Stanford, Chem. Eng. J., 161, 114 (2010).

17. L.M. Ravelo-Pérez, J. Hernández-Borges and M.Á. Rodríguez-Delgado, J. Chromatogr. A, 1211, 33 (2008).

18. K.L. Strong, D.P. Anderson, K. Lafdi and J.N. Kuhn, Carbon, 41, 1477 (2003).

19. F. Yu, J. Ma and Y.Q. Wu, J. Hazard. Mater., 192, 1370 (2011).

20. C.-H. Wu, J. Hazard. Mater., 144, 93 (2007).

21. K. Yang and B. Xing, Environ. Pollut., 157, 1095 (2009).

22. N.V. Perez-Aguilar, P.E. Diaz-Flores and J.R. Rangel-Mendez, J. Colloid Interf. Sci., 364, 279 (2011).

23. Z. Yue and J. Economy, J. Nanoparticle Res., 7, 477 (2005).

24. Q.H. Fan, D.D. Shao, J. Hu, C.L. Chen, W.S. Wu and X.K. Wang, Radiochim. Acta, 97, 141 (2009).

25. X.M. Ren, C.L. Chen, M. Nagats and X.K. Wang, Chem. Eng. J., 170, 395 (2011)

27. J.H. Wang, X.J. Han, H.R. Ma, Y.F. Ji and L.J. Bi, Chem. Eng. J., 173, 171 (2011).

28. L.H. Ai, C.Y. Zhang, F. Liao, Y. Wang, M. Li, L.Y. Meng and J. Jiang, J. Hazard. Mater., 198, 282 (2011).

29. S. Brunauer, P.H. Emmett and E. Teller, J. Am. Chem. Soc., 60, 309 (1938).

30. H.M.F. Freundlich, J. Phys. Chem., 57, 385 (1906).

31. W.J. Weber Jr., P.M. McGinley and L.K. Katz, Environ. Sci. Technol., 26, 1955 (1992).

32. F. Kano, I. Abe, H. Kamaya and I. Ueda, Surf. Sci., 467, 131 (2000).

33. I. Langmuir, J. Am. Chem. Soc., 38, 2221 (1916).

34. B. Xing, J.J. Pignatello and B. Gigliotti, Environ. Sci. Technol, 30, 2432 (1996).

35. G. Xia and W.P. Ball, Environ. Sci. Technol., 33, 262 (1999).

36. J. Toth, Acta Chim. Acad. Hung., 69, 311 (1971).

37. M. Ahmadian, N. Yosefi, A. Toolabi, N. Khanjani, S. Rahimi and A. Fatehizadeh, Asian J. Chem., 24, 3094 (2012). 